\title{
PENGARUH PERMAINAN SMART BALL TERHADAP KEMAMPUAN MENGENAL WARNA PADA ANAK USIA DINI
}

\author{
Susi Maulida1, Umi Fauziyah ${ }^{2}$ \\ ${ }^{1}$ STITNU Al Hikmah Mojokerto, ${ }^{2}$ STITNU Al Hikmah Mojokerto \\ e-mail: 1stitnumjk.susimaulida@gmail.com, fauziyahumi96@gmail.com,
}

$\begin{array}{lcc}\text { Diterima: } 6 \text { Juni } 2020 & \text { I Direvisi: } 10 \text { Juni } 2020 & \text { I Disetujui: } 11 \text { Juni } 2020 \\ \text { (C)2019 Pendidikan Guru Raudhatul Atfhal Fakultas Agama Islam Universitas Islam Malang }\end{array}$

\begin{abstract}
Child's cognitive development involves learning skills in children that occur through complex internal processes and mental activities. Children who develop both cognitive aspects will be able to learn to develop thought processes, respond to objects in their environment and reflect on their experiences. Sometimes children are not able to recognize colors because it is not usual to mention various colors and the limitations of the media to recognize colors when at school. Children only know certain colors that are often seen for example green because children see leaves, red and white when children see the flag and when children are faced with different objects the child will have difficulty guessing the color. Smart ball is a game tool that can develop children's cognitive play methods. Smart ball has advantages in developing all aspects of child development, especially in aspects of cognitive development, namely children are able to recognize colors. The approach in this research is a quantitative approach. Data collected in this study are descriptive. The process to be observed is student activities and teacher activities during the learning process. From the results of an analysis of the effect of smart ball on the ability to recognize colors, the results of research show that smartball games affect the ability to recognize children's colors.
\end{abstract}

Keywords: Smart ball, Get to Know Color, Early Childhood

\section{A. Pendahuluan}

Pendidikan anak usia dini sangatlah penting untuk menumbuh kembangkan seluruh aspek perkembangan anak yang nantinya bisa melihat potensi anak, tumbuh kembang anak usia dini dapat ditumbuh kembangkan sejak usia dini ini karena pada usia ini anak lebih ingin menampilkan dan mencari sesuatu yang diinginkannya (Martella \& Connors-Tadros, 2014). Karena pentingnya dalam pertumbuhan pada usia ini sehingga usia dini sering disebut the golden age (usia

This work is licensed under Creative Commons Attribution Non Commercial 4.0 International License Available online on: http://riset.unisma.ac.id/index.php/fai/index 
emas). Setelah melihat penyataan tersebut dapat disimpulkan bahwa jika ingin membuat anak menjadi anak yang berkualitas, maka pendidikan anak tersebut harus dilakukan sejak usia dini dengan Pendidikan Anak Usia Dini ( PAUD). Pada masa ini khususnya usia 4-5 tahun anak mengalami masa peka, dimana anak lebih cepat dalam menerima berbagai stimulus(Edwards, 2014).

Kecerdasan anak tidak hanya diukur dari sisi neurologi (optimalisasi fungsi otak) semata, tetapi juga diukur dari sisi psikologi, yaitu tahap-tahap perkembangan atau tumbuh cerdas. Artinya, anak yang cerdas bukan hanya yang otaknya berkembang cepat, tetapi juga cepat dalam pertumbuhan dan perkembangan pada aspek-aspek yang lain. Kecerdasan pada aspek- aspek yang lain ini ditentukan oleh tingkat pencapaian tumbuh-kembang pada semua aspek anak. Aspek-aspek yang dimaksud adalah fisik-motorik, bahasa, kognitif, sosialemosional, dan rasa beragama. Semakin lengkap dan sempurna tahap-tahap perkembangan pada semua aspek itu, semakin sempurna kecerdasan anak tersebut. Sebaliknya, semakin rendah tingkat pencapaian perkembangan pada semua aspek di atas, semakin rendah pula tingkat kecerdasannya (Suyadi, 2010:65).

Salah satu aspek perkembangan anak yang penting untuk dikembangkan yaitu perkembangan kognitif. Kognitif adalah suatu proses berpikir, yaitu kemampuan individu untuk menghubungkan, menilai, dan mempertimbangkan suatu kejadian atau peristiwa. Proses kognitif berhubungan dengan tingkat kecerdasan (inteligensi) yang menandai seseorang dengan berbagai minat terutama sekali ditujukan kepada ide-ide dan belajar. Beberapa ahli yang berkecimpung dalam bidang.

Perkembangan kognitif anak 4-5 tahun menurut Satuan Tingkat Pencapaian Perkembangan Anak meliputi belajar dan pemecahan masalah, berfikir logis dan berfikir simbolik (Aljojo et al., 2019). Lingkup perkembangan berfikir logis dibagi antara lain mengklasifikasikan benda berdasarkan fungsi, bentuk atau warna atau ukuran, mengenal gejala sebab-akibat yang terkait dengan dirinya mengklasifikasikan benda ke dalam kelompok yang sama atau kelompok yang sejenis atau kelompok yang berpasangan dengan 2 variasi, mengenal pola (misal, $\mathrm{AB}-\mathrm{AB}$ dan $\mathrm{ABC}-\mathrm{ABC}$ ) dan mengulanginya, mengurutkan benda berdasarkan 5 seriasi ukuran atau warna.

Dalam perkembangan kognitif anak melibatkan keterampilan belajar pada anak yang terjadi melalui proses dan kegiatan mental internal yang kompleks (Piaget, 1977). Anak yang berkembang baik aspek kognitifnya akan dapat belajar mengembangkan proses berfikir, merespon objek dilingkungannya dan merefleksikan pengalamannya. Terkadang anak belum mampu mengenal warna 
karena tidak terbiasanya menyebutkan macam-macam warna dan keterbatasan media untuk mengenal warna ketika di sekolah. Anak hanya mengenal warnawarna tertentu yang sering dilihat misalnya hijau karena anak melihat daun, merah dan putih ketika anak melihat bendera dan ketika anak dihadapkan kepada benda yang berbeda anak akan kesulitan menebak warnanya.

Pada saat usia lima tahun pertama dalam kehidupan anak, motorik kasar inilah lebih dominan berkembang (Edwards, 2014). Motorik kasar anak, berkembang sejalan dengan pertambahan usia dan kematangan saraf serta otototot anak. Menurut Sudjiono (2007: 1.5 ) menjelaskan mengenai efek penting dari peningkatan kemampuan motorik kasar. Secara langsung pertumbuhan motorik kasar anak menentukan keterampilannya dalam bergerak. Sementara itu secara tidak langsung, pertumbuhan dan perkembangan kemampuan motorik kasar anak mempengaruhi cara anak memandang dirinya sendiri dan orang lain. Ini semua akan tercermin dari pola penyesuaian diri anak secara umum. Dari sini dapat disimpulkan bahwa keterampilan motorik kasar yang di dalamnya tercakup keterampilan gerak sangat diperlukan anak untuk bermain.

Permainan smart ball atau games ball adalah suatu alat permainan yang dapat mengembangkan kognitif anak dengan metode bermain (Syamsiah, 2014). Smart ball memiliki kelebihan dalam mengembangkan seluruh aspek perkembangan anak terutama pada aspek perkembangan kognitif yaitu anak mampu mengenal warna. Menurut Maulida (2015) dalam mengembangkan kemampuan motorik di Taman Kanak-kanak sebaiknya menggunakan media yang menarik.

Salah satu media dan atau permainan yang menarik yaitu permainan smart ball. Oleh sebab itu peneliti akan melakukan penelitian dengan judul "Pengaruh Permainan Smart ball terhadap Kemampuan Mengenal Warna Pada Anak Usia Dini di RA Hasyim Asy'ari Desa Suru Kecamatan Dawarblandong Kabupaten Mojokerto". Setelah menemukan judul penelitian, peneliti mendapatkan tujuan ini, yaitu untuk mengetahui pengaruh permainan smart ball terhadap kemampuan mengenal warna pada anak usia dini di RA Hasyim Asy'ari Desa Suru Kecamatan Dawarblandong Kabupaten Mojokerto. Adapun manfaat dari penelitian ini yaitu untuk mengetahui pengaruh permainan smart ball terhadap kemampuan mengenal warna pada anak usia dini di RA Hasyim Asy'ari Desa Suru Kecamatan Dawarblandong Kabupaten Mojokerto". 


\section{B. Metode}

Pendekatan dalam penelitian ini adalah pendekatan kuantitatif. Data yang dikumpulkan dalam penelitian ini bersifat deskriptif. Proses yang akan diamati adalah aktivitas siswa dan aktivitas guru selama proses pembelajaran berlangsung. Penelitian ini mengunakan metode kuantitatif. Penelitian dilaksanakan sesuai kondisi di lapangan pada saat itu. Penelitian ini bertujuan untuk mengatahui seberapa besar Pengaruh Permainan Smart ball terhadap Kemampuan Mengenal Warna Pada Anak Usia Dini di RA Hasyim Asy'ari Desa Suru Kecamatan Dawarblandong Kabupaten Mojokerto. Penelitian ini mengambil tempat di Sekolah RA Hasyim Asy'ari Kec. Dawarblandong. Waktu penelitian dimulai sejak pengajuan proposal sampai selesai penyusunan laporan.

Penelitian ini menggunakan angka-angka dalam statistic guna penyajian data dan analisis. Metode penelitian ini sesuai dengan harapan peneliti. Perhatian utama dalam penelitian ini menyangkut bagaimana pengaruh permainan smar ball terhadap kemampuan mengenal warna anak usia dini. Subjek dan objek penelitian ini adalah: anak-anak RA Hasyim Asy'ari yang menjadi subyek penelitian dalam penyusunan penelitian ini. Dalam penelitian ini peneliti menggunakan angkaangka dan uraian untuk mencari makna sehingga akan menghasilkan suatu informasi. Sampel yang digunakan dalam penelitian adalah siswa-siswi kelompok A RA Hasyim Asy'ari yang berjumlah 20 anak.

Teknik Pengumpul Data pada penelitian ini terdiri dari : (1). Data primer yaitu data/ informasi yang diperoleh langsung di lapangan yang berupa data mentah yaitu dari siswa dan guru kelas kelompok B antara lain: a). Kuesioner, yaitu dengan memberikan pertanyaan-pertanyaan untuk anak kelompok A RA Hasyim Asy'ari berupa daftar pertanyaan dimana pertanyaan sudah dirumuskan sedemikian rupa, responden tinggal memilih salah satu dari jawaban yang dikehendaki yang bertujuan untuk menghindari penyimpangan dalam menjawab pertanyaan, b). Observasi, yaitu cara pengumpulan data dengan cara mengadakan pengamatan langsung pada kegiatan pembelajaran yang terjadi dikelas dan terhadap objek yang diteliti. c). Dokumentasi yaitu cara untuk mengumpulkan data-data yang meliputi benda-benda tertulis berupa arsip-arsip, surat keputusan, rekaman suara dan photo-photo yang berhubungan dengan masalah penelitian.

\section{Hasil dan Pembahasan}

Sebelum melakukan penelitian di RA Hasyim Asy'ari, telah dilakukan observasi awal untuk menemukan masalah sebagai bahan dalam penelitian. Dalam penelitian yang dilakukan peneliti ketika mengajar melihat didalam kelas kelompok A belum pernah dilakukan penelitian menggunakan media smart ball 
untuk mengembangkan aspek perkembangan kognitif terutama mengenal warna, anak masih merasa bingung dalam membedakan dan mengelompokkan warna dikarenakan terlalu banyak warna yang dipelajari dan beberapa warna terkesan sama misalnya biru dengan hijau, kuning dengan jingga. Hal ini disebabkan karena kurangnya pengetahuan anak tentang warna dan terbatasnya media yang diketahui anak untuk mengenal warna. Pada penelitian ini adalah mengenalkan warna menggunakan media smartball dengan cara bermain yang menyenangkan.

Pada penelitian ini mengungkap bahwa berkaitan dengan pengaruh bermain smart ball terhadap kemampuan mengenal warna pada anak kelompok A di RA Hasyim Asy'ari sesuai dengan teori yang dikemukakan oleh Paramita (2010:141) bahwa pengenalan warna merupakan aktifitas yang mudah dibuat dan menyenangkan, melalui berbagai media, seni pengenalan warna tidak hanya untuk anak-anak, namun juga orang dewasa. Hasil penelitian ini juga sesuai dengan teori yang dikemukakan oleh Montolalu (2008:1.2), Dalam kehidupan anak bermain mempunyai arti yang sangat penting. Dapat dikatakan bahwa setiap anak yang sehat selalu mempunyai dorongan untuk bermain sehingga dapat dipastikan bahwa anak yang tidak bermain-main pada umunya dalam keadaan sakit, jasmaniah ataupun rohaniah. Sejalan dengan Montolalu, Anggani (dalam Yetri 2014:231) Bermain adalah suatu kegiatan yang dilakukan dengan atau tanpa mempergunakan alat yang menghasilkan pengertian atau memberikan informasi, memberikan kesenangan maupun pengembangan imajinasi pada anak.

Smart ball juga berperan dalam hal mengenal warna anak dikarenakan warna dari bola pada smart ball itu sendiri sangat bermacam- macam jadi mempermudah anak dalam mengenal warna menggunakan lego. Sesuai dengan teori Vigotsky (dalam Zaman dkk, 2010:1.21) mengungkapkan anak mengkontruksi pengetahuannya berdasarkan pengalamannya. Sebagaimana halnya mainan berbentuk balok dan mainan konstruktif lainnya, lego merupakan permainan konstruktif bermanfaat bagi anak untuk mengembangkan kognitifnya.

Tabel 1. Kemampuan Siswa Sebelum dan Sesudah Penerapan Permainan Smart ball

\begin{tabular}{|l|l|l|}
\hline \multicolumn{1}{|c|}{ Indikator } & \multicolumn{1}{|c|}{$\begin{array}{c}\text { Sebelum } \\
\text { penelitian }\end{array}$} & $\begin{array}{c}\text { Sesudah } \\
\text { penelitian }\end{array}$ \\
\hline $\begin{array}{l}\text { Mengklasifikasikan benda berdasarkan } \\
\text { fungsi, bentuk atau warna atau ukuran. }\end{array}$ & $45 \%$ & $70 \%$ \\
\hline $\begin{array}{l}\text { Mengklasifikasikan benda ke dalam } \\
\text { kelompok yang sama atau kelompok yang }\end{array}$ & $50 \%$ & $75 \%$ \\
\hline
\end{tabular}




\begin{tabular}{|l|l|l|}
\hline \multicolumn{1}{|c|}{ Indikator } & \multicolumn{1}{|c|}{$\begin{array}{c}\text { Sebelum } \\
\text { penelitian }\end{array}$} & $\begin{array}{c}\text { Sesudah } \\
\text { penelitian }\end{array}$ \\
\hline $\begin{array}{l}\text { sejenis atau kelompok yang berpasangan } \\
\text { dengan 2 variasi. }\end{array}$ & & $75 \%$ \\
\hline $\begin{array}{l}\text { Mengenal pola (misal, AB-AB dan ABC- } \\
\text { ABC) dan mengulanginya. }\end{array}$ & $40 \%$ & $80 \%$ \\
\hline $\begin{array}{l}\text { Mengurutkan benda berdasarkan 5 } \\
\text { seriasi ukuran atau warna. }\end{array}$ & $55 \%$ & \\
\hline
\end{tabular}

Dari tabel diatas terlihat bahwa hasil peningkatan yang cukup signifikan. Sehingga dapat disimpulkan bahwa penggunaan permainan smart ball dapat meningkatkan perkembangan kognitif anak.

\section{Simpulan}

Permainan smart ball ini sangat membutuhkan peran anak karena menggunakan 3 tahapan, yaitu pemompaan, penempatan bola dengan lubang yang warnanya sama, dan pencarian kata yang sesuai dengan gambar tempat bola jatuh. Permainan ini sangat mengembangkan seluruh aspek perkembangan, terutama pada aspek perkembangan kognitif dimana anak mampu mengenal warna dari kegiatan memasukkan bola sesuai dengan lubangnya. Dengan adanya smart ball ini sudah pasti memberikan dampak yang baik bagi siswa dan bias membuat siswa lebih berprestasi dengan mampunya mereka membedakan warna dari kegiatan tersebut.

\section{Daftar Rujukan}

Aljojo, N., Munshi, A., Almukadi, W., Zainol, A., Alanaya, I., Albalawi, H., Alharbi, G., Almadani, N., Almohammadi, E., Kadu, A., \& Abdulghaffar, N. A. (2019). The design and implementation of an arabic pronunciation application for early childhood. Journal of Technology and Science Education, 9(2), 136-152. https://doi.org/10.3926/jotse.486

Edwards, S. (2014). Teaching through assessment: reconsidering the transfer problem through a convergence of technology and assessment in early childhood teacher education. Teachers and Teaching: Theory and Practice, December 2014, 37-41. https://doi.org/10.1080/13540602.2012.709733

Montolalu Dkk. (2008). Bermain daan Permainan Anak. Jakarta: Universitas Terbuka.

Martella, J., \& Connors-Tadros, L. (2014). Evaluating Early Childhood Educators: Prekindergarten through Third Grade. Supplement to the "Practical Guide to Designing Comprehensive Educator Evaluation Systems" (Issue October, pp. 1- 
46). http://search.proquest.com/docview/1697495520?accountid=13042 Paramita, Ecka. (2010). Dahsyatnya Anak Usia Emas. Yogyakarta: Intrepreebook Prestasi.

Piaget, J. (1977). The Essential Piaget (J. J. V. Howard E. Gruber (ed.); 2nd ed.). J. Aronson.

Sugiyono. (2009). Metode Penelitian Pendidikan, Pendekatan Kuantitatif, Kualitatif dan $R \& D$. Bandung: Alfabeta

Sujiono, B. (2007). Metode Pengembangan Fisik. Jakarta : Universitas Terbuka. Suyadi. (2010). Psikologi Belajar PAUD. Yogyakarta: PT Pustaka Insan Madani. Syamsiah. (2014). Meningkatkan Kecerdasan Kinestetik Melalui Games Ball (Permainan Bola) Pada Anak Kelompok Bermain Masjid Syuhada. Skripsi. Yogyakarta: Universitas Negerai Yogyakarta.

Zaman, dkk. (2010). Media dan Sumber Belajar TK. Jakarta: Universitas Terbuka Maulida, S., \&amp; Setyowati, S. (2015). Pengaruh Media Bubur Koran Terhadap Kemampuan Motorik Halus Anak. PAUD Teratai. Jurnal Pendidikan Anak Usia Dini. 4 (1). Surabaya: Universitas Negeri Surabaya. 